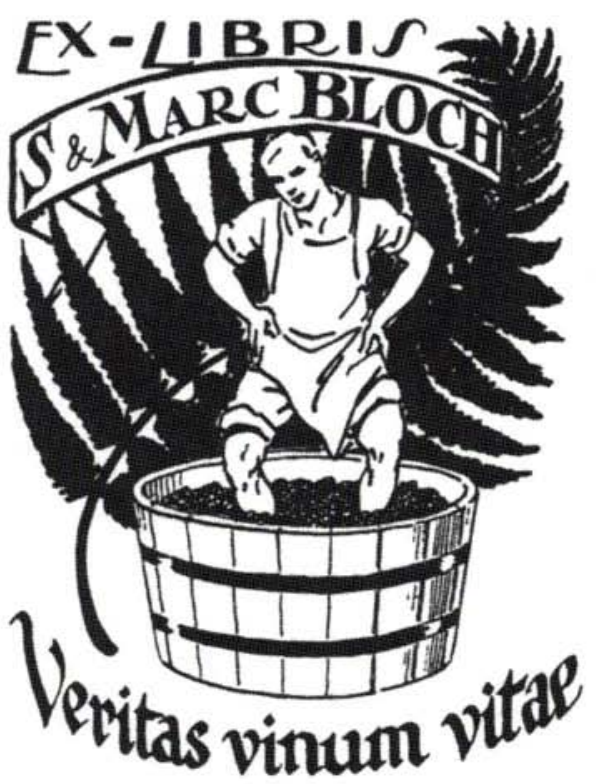





\section{Werner Paravicini}

\section{Die Wahrheit der Historiker}

R. Oldenbourg Verlag München 2010 


\section{Anke}

nach mehr als vierzig Jahren

Bibliografische Information der Deutschen Nationalbibliothek

Die Deutsche Nationalbibliothek verzeichnet diese Publikation in der Deutschen Nationalbibliografie; detaillierte bibliografische Daten sind im Internet über <http://dnb.d-nb.de> abrufbar.

(C) 2010 Oldenbourg Wissenschaftsverlag GmbH, München

Rosenheimer Straße 145, D-81671 München

Internet: oldenbourg.de

Das Werk einschließlich aller Abbildungen ist urheberrechtlich geschützt. Jede Verwertung außerhalb der Grenzen des Urheberrechtsgesetzes ist ohne Zustimmung des Verlages unzulässig und strafbar. Dies gilt insbesondere für Vervielfältigungen, Übersetzungen, Mikroverfilmungen und die Einspeicherung und Bearbeitung in elektronischen Systemen.

Umschlaggestaltung: Sarah Voit

Frontispiz: Marc Blochs Exlibris, ca. 1935 @ Étienne Bloch, Saint-Lubin-de-la-Haye Gedruckt auf säurefreiem, alterungsbeständigem Papier (chlorfrei gebleicht).

Satz: Typodata GmbH, München

Druck: Memminger MedienCentrum, Memmingen

Bindung: Buchbinderei Klotz, Jettingen-Scheppach

ISBN 978-3-486-70105-0

eISBN 978-3-486-70395-5 